\title{
Sterol Requirement of Mating Strains of Heterothallic Phytophthoras
}

\author{
By C. G. ELLIOTT* AND B. GLEN \\ Botany Department, University of Glasgow, Glasgow G12 8QQ, U.K.
}

(Received 26 August 1981)

The induction by A2 strains of Phytophthora parasitica and Phytophthora palmivora of sexual reproduction in an A1 strain of $P$. parasitica has been studied using synthetic medium with and without sterol, the strains being separated by a polycarbonate membrane. Production of the inducing $\alpha 2$ hormone by the A2 strain does not appear to require sterol, but sterol greatly enhances the response to the inducing hormone by the A1 strain as well as being required for subsequent oospore development.

\section{INTRODUCTION}

Sexual reproduction in heterothallic species of Phytophthora requires the interaction of strains of two mating types, designated A1 and A2. This interaction has been studied by Ko $(1978,1980)$ by having the paired complementary strains separated by a polycarbonate membrane. The membrane is not penetrated by the hyphae, but Ko has shown that some substance must be produced by the A2 strain which diffuses through the membrane and induces reproduction in the A1 strain, leading to development of antheridia and oogonia and production of selfed oospores. Ko has called this inducing substance $\alpha 2$ hormone. The A1 strain also produces an $\alpha 1$ hormone which induces oospore formation in A2 strains.

Sexual reproduction in Phytophthora requires the presence of sterols in the medium. The fungi are unable to synthesize sterols, and it has been argued that the required sterols are metabolized to steroid hormones which control sexual development (Elliott, 1982; Elliott \& Sansome, 1977). The distinction between induction and subsequent sexual development is important. The later stages of development (meiosis and oospore formation) show specific steroid requirements (Elliott \& Sansome, 1977). The use of Ko's system now enables us to examine whether the induction process is also sterol dependent. Ko's experiments provide no information on this point as V8 juice medium was used throughout. We report experiments in which the strains were grown on synthetic medium, with and without sterols, which were intended to show whether the production of $\alpha$ hormone requires the presence of sterol.

\section{METHODS}

The strains used were: A1 mating type - Phytophthora parasitica (P. nicotianae var. parasitica) P991; A2 mating type - $P$. parasitica P731 and P. palmivora P255 (IMI 189732).

The medium contained, per litre: $10 \mathrm{~g}$ sucrose, $1.5 \mathrm{~g}$ monosodium glutamate monohydrate, $0.5 \mathrm{~g} \mathrm{KH}_{2} \mathrm{PO}_{4}$, $0.25 \mathrm{~g} \mathrm{MgSO}_{4} .7 \mathrm{H}_{2} \mathrm{O}, 0.1 \mathrm{~g} \mathrm{CaCl}_{2}, 1 \mathrm{ml}$ trace element solution (Elliott \& Knights, 1981), $1 \mathrm{mg}$ thamin hydrochloride, $1.0 \mathrm{~g}$ Tween 80,0 or $10 \mathrm{mg}$ cholesterol or sitosterol, $10.0 \mathrm{~g}$ Oxoid agar no. 3 . The Tween 80 and sterol were dissolved in acetone and added after autoclaving ( $1 \mathrm{ml}$ of each solution per $100 \mathrm{ml} \mathrm{medium})$.

Medium was dispensed in $35 \mathrm{~mm}$ plastic Petri dishes, $3 \mathrm{ml}$ per dish, inoculated centrally and incubated at $25^{\circ} \mathrm{C}$. Cultures of the required age (generally $6 \mathrm{~d}$ for both mating types) were removed whole from the small plastic dishes and placed one above the other in $9 \mathrm{~cm}$ glass Petri dishes with a $47 \mathrm{~mm}$ polycarbonate membrane (CPR $0.2 \mu \mathrm{m}$; Nuclepore Corporation, Pleasanton, Calif., U.S.A.) between them. Oogonia and oospores were subsequently counted in the $\mathbf{P 9 9 1}$ strain, in two radial transects, $0.26 \mathrm{~mm}$ wide, in each dish. 
For measurement of transfer of steroid material between paired strains, approximately $1 \mu \mathrm{Ci}(37 \mathrm{kBq}) \mathrm{high}$ specific activity $\left[{ }^{14} \mathrm{C}\right]$ cholesterol (Amersham) was added to $100 \mathrm{ml}$ medium together with the unlabelled cholesterol, and cultures were grown and paired in the usual way, a radioactively labelled culture (donor) being paired with an unlabelled culture (recipient) across a polycarbonate membrane. When the cultures were separated, they were placed individually in scintillation vials, and freeze-dried. Scintillant $[0.4 \%(\mathrm{w} / \mathrm{v})$ PPO in toluene] was added, and the radioactivity in each donor and recipient pair was measured after allowing several days for material in the dried culture to equilibrate with the toluene.

Metabolism of the labelled material was studied by extracting a number of dried recipient and donor cultures with chloroform/methanol $(2: 1, \mathrm{v} / \mathrm{v})$, and making autoradiographs of a thin-layer chromatogram of the extracts.

\section{RESULTS AND DISCUSSION}

Oogonia and oospores were formed in the P991 cultures as detailed below, but not in P731 or P255 under the conditions of these experiments. Chlamydospores were however formed by P731 and P255 when the medium contained sterol.

The results in Table 1 show:

(i) The Al strain P991 grown on sterol-containing medium formed similar numbers of oospores regardless of whether the A2 strain it was paired with was on sterol-containing or on non-sterol medium (Table 1, rows marked $a$ and $b$ ).

(ii) Some oospores were formed by the A1 strain when it was on non-sterol medium but the A2 was on sterol-containing medium (rows $c$ ).

(iii) Oogonia but no oospores were formed when neither strain had added sterol (rows $d$ ). This was also the case when Tween 80 was omitted from the medium. Tween 80 had little effect on reproduction. It is possible that some sterol was carried over in the inoculum.

Point (i) suggested that production of $\alpha 2$ hormone does not require the presence of sterol. From point (ii) we supposed that sterol could diffuse from A2 to A1 and supply the A1 strain's sterol requirement for oospore development when it was on non-sterol medium. [No oospores form in the absence of sterol: point (iii).] It was therefore thought possible that sterol could diffuse from $A 1$ to $A 2$ and that this might enhance the production of $\alpha 2$ when the A2 strain was on non-sterol medium (the rows $b$ situation), although induction of the A1 strain occurred in the apparent absence of sterol. We therefore measured transfer of labelled material between strains when one of them was grown with $\left[{ }^{14} \mathrm{C}\right]$ cholesterol (Tables 2 and 3 ).

Very little material diffused from a labelled culture to uninoculated medium (Table 2, rows $3 a$ and $b$ ); virtually all of it was bound in the mycelium. A small amount of labelled material was transferred to a culture grown without sterol (rows $2 a$ and $b$ ), but there was also transfer of label to cultures on sterol-containing medium (rows $1 a$ and $b$ ), so there is a dynamic equilibrium between cholesterol in the mycelium and the medium. Thin-layer chromatography of the labelled material extracted from recipient cultures showed radioactivity at positions corresponding to free sterol, sterol ester and polar derivatives; their relative amounts were characteristic of cholesterol taken up and metabolized by Phytophthora (Elliott \& Knights, 1974, 1981). Cholesterol (or its esters: Elliott \& Knights, 1981 ) is clearly the main substance transferred, but it is possible that trace amounts of a sterol metabolite could also be transferred.

More labelled material was transferred from P731 to P991 than from P991 to P731 (significant in Table 2, rows $2 a$ and $b$, and Table 3 , rows $1 a$ and $b, 4 a$ and $b$; difference not significant in Table 2, $1 a$ and $b$ ). P991 appeared to bind sterol more tightly than P731 (Table $3,5 a$ significantly less than $5 b$, and $3 a$ is less than $3 b$ though not significantly so), perhaps because it forms more mycelium (dry weights of cultures in $15 \mathrm{ml}$ liquid medium after $7 \mathrm{~d}$ were $83.4 \mathrm{mg}$ (s.E. $2.55 \mathrm{mg}$ ) for P991 and $73.4 \mathrm{mg}$ (s.E. $1.73 \mathrm{mg}$ ) for P731; difference significant at $1 \%$ level) and thus has more cholesterol-binding sites. More cholesterol was transferred from P255 to P991 than the reverse (Table 3, $2 a$ and $b$ ); however, P255 appeared to bind sterol more strongly ( $3 c$ is less than $3 a$, Table 3 ). 
Table 1. Production of oogonia and oospores by Phytophthora parasitica P991 in pairings with P. parasitica P731 or P. palmivora P255 (two experiments)

Cultures were grown for $6 \mathrm{~d}$, then paired with a polycarbonate membrane between them. P991 was on top in Expt 1 and underneath in Expt 2 in all dishes. The cultures were examined after 10-11 d (Expt 1) or $7 \mathrm{~d}$ (Expt 2). Two counts were made in each of five dishes, except those marked * where there were two counts in each of four dishes.

\begin{tabular}{|c|c|c|c|c|c|}
\hline & & Pairing $\dagger$ & $\begin{array}{l}\text { No. of oospores } \\
\text { [range (median)] }\end{array}$ & $\begin{array}{l}\text { Total no. of oogonia } \\
\text { [range (median)] }\end{array}$ & $\begin{array}{c}\text { Mean percentage of } \\
\text { oogonia forming oospores }\end{array}$ \\
\hline Expt 1 & $\begin{array}{l}a \\
b \\
c \\
d\end{array}$ & $\begin{array}{l}\mathrm{P} 991 \mathrm{C} / \mathrm{P} 731 \mathrm{C} \\
\mathrm{P} 991 \mathrm{C} / \mathrm{P} 731- \\
\mathrm{P} 991-/ \mathrm{P} 731 \mathrm{C} \\
\mathrm{P} 991-/ \mathrm{P} 731-\end{array}$ & $\begin{array}{cc}32-233 & (94) \\
65-306 & (136 \cdot 5) \\
30-139 & (48 \cdot 5) \\
0 & \end{array}$ & $\begin{array}{l}35-250(113 \cdot 5) \\
67-309(147) \\
63-369(110) \\
50-153(84 \cdot 5)\end{array}$ & $\begin{array}{c}85 \cdot 1 \\
95 \cdot 5 \\
43 \cdot 6 \\
0\end{array}$ \\
\hline & $\begin{array}{l}a \\
b \\
c \\
d\end{array}$ & $\begin{array}{l}\text { P991C/P255C } \\
\text { P991C/P255- } \\
\text { P991-/P255C } \\
\text { P991-/P255- }\end{array}$ & $\begin{array}{l}176-339(226 \cdot 5) \\
130-520(321 \cdot 5) \\
185-398(300 \cdot 5) \\
0\end{array}$ & $\begin{array}{r}190-348(242 \cdot 5) \\
147-545(340 \cdot 5) \\
269-538(385 \cdot 5) \\
52-244(186 \cdot 5)\end{array}$ & $\begin{array}{c}92 \cdot 1 \\
92 \cdot 7 \\
72 \cdot 8 \\
0\end{array}$ \\
\hline Expt 2 & $\begin{array}{l}a \\
b \\
c\end{array}$ & $\begin{array}{l}\text { P991C/P731C } \\
\text { P991C/P731- } \\
\text { P991-/P731C }\end{array}$ & $\begin{aligned} 63-310 & (114 \cdot 5) \\
46-178 & (84) \\
1-129 & (56)\end{aligned}$ & $\begin{array}{l}90-360(180 \cdot 5) \\
76-233(122 \cdot 5) \\
35-275(159.5)\end{array}$ & $\begin{array}{l}69.9 \\
67.4 \\
31 \cdot 1\end{array}$ \\
\hline & $\begin{array}{l}a \\
b \\
c\end{array}$ & $\begin{array}{l}\text { P991C/P255C } \\
\text { P991C/P255-* } \\
\text { P991-/P255C* }\end{array}$ & $\begin{array}{ll}80-354 & (220) \\
19-139 & (63) \\
31-92 & (56 \cdot 5)\end{array}$ & $\begin{array}{c}183-408(295) \\
48-187(108) \\
45-250(142 \cdot 5)\end{array}$ & $\begin{array}{l}75 \cdot 3 \\
59 \cdot 3 \\
43 \cdot 4\end{array}$ \\
\hline
\end{tabular}

\section{Table 2. Transfer of material between paired cultures, one of which was grown on medium} with $\left[{ }^{14} \mathrm{C}\right]$ cholesterol One culture of each pair had medium with approximately 170000 c.p.m. $\left[{ }^{14} \mathrm{C}\right]$ cholesterol. Cultures
were grown for $7 \mathrm{~d}$, paired for 2 or $7 \mathrm{~d}$, then separated and radioactivity in each member of the pair
measured as described in Methods. There were four replicates of each treatment.

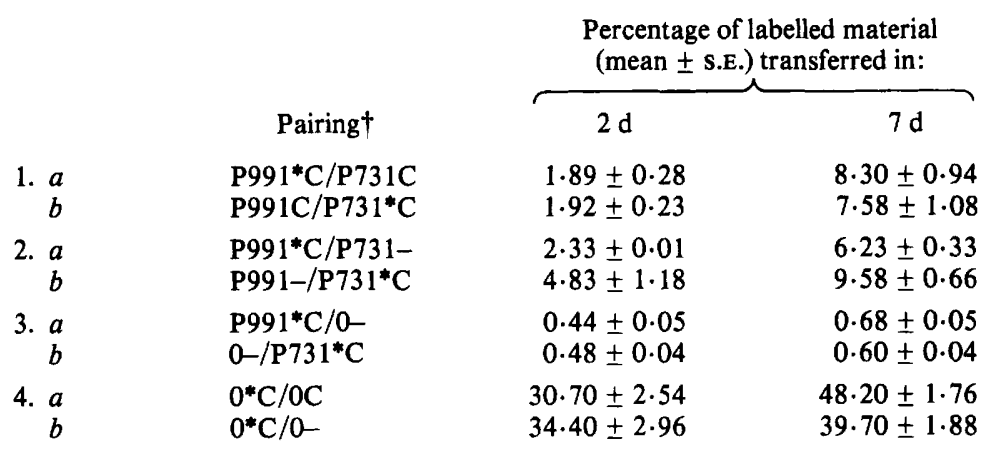

$\dagger 0$, Uninoculated medium; ${ }^{*} \mathrm{C}$, medium with $\left[{ }^{14} \mathrm{C}\right]$ cholesterol; $\mathrm{C}$, medium with unlabelled cholesterol; - , medium without cholesterol.

Thus it appears that cholesterol was transferred from the A2 culture to the A1 culture when the latter was on non-sterol medium, and this could supply the sterol requirement for oospore development by the A 1 strain (as Table 1 , rows $c$ ). The possibility that $\alpha 2$ hormone production was enhanced by sterol was not resolved by these experiments, in which the cultures remained paired for $7 \mathrm{~d}$ or more. We therefore performed an experiment in which the cultures were paired for various short lengths of time, after which the A2 strain was removed and the A1 strain incubated alone. In similar experiments, Yu et al. (1981) have shown that induction can occur in only a few hours. 
Table 3. Transfer of material between paired cultures, one of which was grown on medium with $\left[{ }^{14} \mathrm{C}\right]$ cholesterol (two experiments)

One culture of each pair had medium with approximately 88000 c.p.m. $\left[{ }^{14} \mathrm{C}\right]$ cholesterol (left-hand expt) or 106000 c.p.m. (right-hand expt). Cultures were grown for $6 \mathrm{~d}$ (left-hand expt) or $7 \mathrm{~d}$ (right-hand expt), paired for $2 \mathrm{~d}$, then separated and radioactivity in each member of the pair measured. There were five (left-hand expt) or four (right-hand expt) replicates of each treatment.

\begin{tabular}{|c|c|c|c|c|c|}
\hline & Pairing $\dagger$ & $\begin{array}{l}\text { Percentage of } \\
\text { labelled material } \\
\text { transferred }\end{array}$ & & Pairing $\dagger$ & $\begin{array}{l}\text { Percentage of } \\
\text { labelled material } \\
\text { transferred }\end{array}$ \\
\hline 1. $a$ & $\begin{array}{l}\mathrm{P} 991^{*} \mathrm{C} / \mathrm{P} 731- \\
\mathrm{P} 991-/ \mathrm{P} 731^{*} \mathrm{C}\end{array}$ & $\begin{array}{l}1.24 \\
2.04\end{array}$ & 4. $\frac{a}{b}$ & $\begin{array}{l}\mathrm{P} 991^{*} \mathrm{C} / \mathrm{P} 731 \mathrm{C} \\
\mathrm{P} 991 \mathrm{C} / \mathrm{P} 731^{*} \mathrm{C}\end{array}$ & $\begin{array}{l}0.95 \\
1.96\end{array}$ \\
\hline 2. $\begin{array}{l}a \\
b\end{array}$ & $\begin{array}{l}\mathrm{P} 991^{*} \mathrm{C} / \mathrm{P} 255- \\
\mathrm{P} 991-/ \mathrm{P} 255^{*} \mathrm{C}\end{array}$ & $\begin{array}{l}1 \cdot 04 \\
1 \cdot 31\end{array}$ & 5. $a$ & $\begin{array}{l}\text { P991*C/P991C } \\
\text { P } 731^{*} \mathrm{C} / \mathrm{P} 731 \mathrm{C}\end{array}$ & $\begin{array}{l}1 \cdot 15 \\
1 \cdot 58\end{array}$ \\
\hline 3. $\begin{array}{r}a \\
b \\
c\end{array}$ & $\begin{array}{l}\mathrm{P} 991^{*} \mathrm{C} / \mathrm{P} 991- \\
\mathrm{P} 731^{*} \mathrm{C} / \mathrm{P} 731- \\
\mathrm{P} 255^{*} \mathrm{C} / \mathrm{P} 255-\end{array}$ & $\begin{array}{l}1.47 \\
1.94 \\
1.03\end{array}$ & & & \\
\hline
\end{tabular}

$\dagger^{*} \mathrm{C}$, medium with $\left[{ }^{14} \mathrm{C}\right]$ cholesterol; $\mathrm{C}$, medium with unlabelled cholesterol; - , medium without cholesterol.

Table 4. Formation of oogonia and oospores by P991 following short periods of contact with $P 255$ and transfer of labelled cholesterol between cultures

Cultures were grown for $6 \mathrm{~d}$ and paired for the time stated, with P991 underneath; the P255 culture was then discarded and P991 incubated alone for $7 \mathrm{~d}$. Counts of oogonia and oospores were made in each of five dishes. For the radioactivity transfer experiment, each P255 culture had approximately 70000 c.p.m. $\left[{ }^{14} \mathrm{C}\right]$ cholesterol; there were five replicates.

\begin{tabular}{|c|c|c|c|c|c|c|c|}
\hline & A: P991 & $/ \mathrm{P} 255 \mathrm{C}$ & B: P99 & $/ \mathrm{P} 255$ & C: P99 & $/ \mathrm{P} 255 \mathrm{C}$ & P991-/P255C* \\
\hline $\begin{array}{c}\text { Duration } \\
\text { of } \\
\text { pairing }\end{array}$ & $\begin{array}{l}\text { No. of } \\
\text { oogonia } \\
\text { [range } \\
\text { (median)] }\end{array}$ & $\begin{array}{l}\text { Percentage } \\
\text { forming } \\
\text { oospores }\end{array}$ & $\begin{array}{c}\text { No. of } \\
\text { oogonia } \\
\text { [range } \\
\text { (median)] }\end{array}$ & $\begin{array}{c}\text { Percentage } \\
\text { forming } \\
\text { oospores }\end{array}$ & $\begin{array}{c}\text { No. of } \\
\text { oogonia } \\
\text { [range } \\
\text { (median)] }\end{array}$ & $\begin{array}{l}\text { Percentage } \\
\text { forming } \\
\text { oospores }\end{array}$ & $\begin{array}{c}\text { Percentage } \\
\text { of label } \\
\text { transferred }\end{array}$ \\
\hline $4 \mathrm{~h}$ & $\begin{array}{l}0-11 \\
(2 \cdot 5)\end{array}$ & $>90$ & $\begin{array}{l}4-29 \\
(9 \cdot 5)\end{array}$ & $>90$ & 0 & 0 & 0.20 \\
\hline $8 \mathrm{~h}$ & $\begin{array}{l}17-118 \\
(54 \cdot 5)\end{array}$ & $>90$ & $\begin{array}{c}14-56 \\
(23)\end{array}$ & $>90$ & $\begin{array}{c}0-3 \\
(1 \cdot 5)\end{array}$ & 0 & 0.32 \\
\hline $24 \mathrm{~h}$ & - & & $\begin{array}{c}110-683 \\
(459)\end{array}$ & $>90$ & $\begin{array}{r}4-96 \\
(17 \cdot 5)\end{array}$ & 23 & 0.76 \\
\hline $48 \mathrm{~h}$ & $\begin{array}{c}271-992 \\
(883.5)\end{array}$ & $>90$ & $\begin{array}{c}242-918 \\
(562 \cdot 5)\end{array}$ & $>90$ & $\begin{array}{l}25-202 \\
(67 \cdot 5)\end{array}$ & 40 & $1 \cdot 32$ \\
\hline $7 \mathrm{~d}$ & 一 & & - & & - & & $3 \cdot 16$ \\
\hline
\end{tabular}

The results again show similar oospore development in P991 on cholesterol-containing medium whether or not P255 was on sterol-containing medium (Table 4, A and B). Substantial numbers of oospores were produced by P991 after $8 \mathrm{~h}$ contact with P255 on non-sterol medium, during which time only about $0.3 \%$ of the cholesterol of P991 would have been transferred to P255. A much longer contact with P255 was required for P991 to develop oospores when it was on non-sterol medium and P255 on cholesterol (Table 4, C), and even after $48 \mathrm{~h}$ the structures in P991 scored as oospores were abnormal.

One would expect the greater part of the cholesterol transferred to be incorporated into membranes rather than metabolized to hormones. While not conclusive, the results of this last experiment are most simply interpreted as showing that production of the inducing $\alpha$ hormone 
does not require the presence of sterol, but that sterol greatly increases the capacity for induction (Table 4, A and C) as well as being necessary for oospore development. Sterol has been shown to be especially important to the oogonial parent in the heterothallic Pythium sylvaticum (Pratt \& Mitchell, 1973). Since some oogonia were produced after prolonged contact between the complementary strains in the absence of sterol, induction does not perhaps require its presence.

The volatile substance produced by Trichoderma koningii which induces oospore development in A2 strains (Brasier, 1971, 1975; Pratt et al., 1972), and which thus mimics the effect of $\alpha 2$ hormone, is not a steroid (Sakata \& Rickards, 1980), so it would not be surprising if the $\alpha 1$ and $\alpha 2$ hormones themselves were not steroidal.

\section{REFERENCES}

BRASIER, C. M. (1971). Induction of sexual reproduction in single A2 isolates of Phytophthora species by Trichoderma viride. Nature New Biology 231, 283.

Brasier, C. M. (1975). Stimulation of sex organ formation in Phytophthora by antagonistic species of Trichoderma. I. The effect in vitro. New Phytologist 74, 183-194.

Elliott, C. G. (1982). Physiology of sexual reproduction in Phytophthora. In Phytophthora: its Biology, Ecology and Pathology. Edited by D. C. Erwin, S. Bartnicki-Garcia \& P. H. Tsao. St. Paul, Minnesota: American Phytopathological Society (in the Press).

Elliott, C. G. \& KNiGhts, B. A. (1974). Uptake and metabolism of cholesterol and cholesteryl oleate by Phytophthora cactorum. Biochimica et biophysica acta 360, 78-87.

Elliott, C. G. \& KNights, B. A. (1981). Uptake and interconversion of cholesterol and cholesteryl esters by Phytophthora cactorum. Lipids 16, 1-7.

Elliott, C. G. \& SANSOME, E. (1977). The influence of sterols on meiosis in Phytophthora cactorum. Journal of General Microbiology 98, 141-145.
Ko, W. H. (1978). Heterothallic Phytophthora: evidence for hormonal regulation of sexual reproduction. Journal of General Microbiology 107, 15-18.

Ko, W. H. (1980). Hormonal regulation of sexual reproduction in Phytophthora. Journal of General Microbiology 116, 459-463.

Pratt, B. H., Sedgley, J. H., Heather, W. A. \& SHEPHERD, C. J. (1972). Oospore production in Phytophthora cinnamomi in the presence of Trichoderma koningii. Australian Journal of Biological Sciences 25, 861-863.

Pratt, R. G. \& Mitchell, J. E. (1973). Differential effects of cholesterol in mating thalli of Pythium sylvaticum and Phytophthora capsici. Canadian Journal of Botany 51, 595-599.

Sakata, K. \& Rickards, R. W. (1980). Synthesis of homothallin II. In 23rd Symposium on Chemistry of Natural Products, pp. 165-172. Nagoya, Japan.

Yu, J. Y., Chang, H. S. \& Ko, W. H. (1981). Factors affecting the induction of sexual reproduction in Phytophthora parasitica by $P$. colocasiae. Journal of General Microbiology 123, 249-252. 